\title{
Correction to: Conditional growth volatility and sectoral comovement in U.S. industrial production, 1828-1915
}

\section{Gustavo Freire ${ }^{1}(\mathbb{D}) \cdot$ Marcelo Resende $^{2}$}

Published online: 5 August 2019

(c) Springer-Verlag GmbH Germany, part of Springer Nature 2019

\section{Correction to: Empirical Economics https://doi.org/10.1007/s00181-019-01740-2}

In the original publication of the article, the word "analyzes" should be replaced with "analysis" throughout the article.

The original article has been corrected.

Publisher's Note Springer Nature remains neutral with regard to jurisdictional claims in published maps and institutional affiliations.

The original article can be found online at https://doi.org/10.1007/s00181-019-01740-2.

\section{Marcelo Resende}

mresende@ie.ufrj.br

Gustavo Freire

gustavo.carvalho@fgvmail.br

1 EPGE Brazilian School of Economics and Finance, Praia de Botafogo 190, 11th floor, Rio de Janeiro, RJ 22250-900, Brazil

2 Instituto de Economia, Universidade Federal do Rio de Janeiro, Av. Pasteur 250, Urca, Rio de Janeiro, RJ 22290-240, Brazil 